\title{
Effect of Price and Location on Purchasing Decisions (Case Study of CV. Sumber Anugrah Kota Bandung)
}

\author{
Faishal Rahimi \\ faishalrahimi@uniku.ac.id \\ Kuningan University
}

\begin{abstract}
This research discusses the effect of price and location on purchasing decisions that occur at CV. Sumber Anugrah Bandung. The sample used is 100 respondents or buyers from the store. This research is a causal research with Validity, Reliability, Classical Assumption testing, and Hypothesis testing. From this test, the results of the study indicate that Price and Location have a moderately positive effect on Purchasing Decisions. Price and location together have a significant influence on purchasing decisions.
\end{abstract}

\section{Keywords: Price, Location, Purchase Decision}

JEL Classification: M30

\section{INTRODUCTION}

Marketing activities have a critical role in the business world, given the orientation towards society (consumers). The state of the business world changes dynamically, along with changes in consumer tastes and changes in the surrounding environment. Consumer needs that continue to increase become business opportunities. This becomes the rationale for business actors or businesses to meet the needs, wants and expectations of consumers so that consumers do not turn to competitors despite changes.

In such intense competition, the company's success is mostly determined by the company's determination to take advantage of opportunities and identify individual activities in its business or business. Many companies try to win the competition by taking advantage of existing business opportunities and trying to implement the right marketing strategy in order to dominate the market. One of the company's goals is to maintain the existence of its performance to achieve a specific growth rate. Marketing is one of the activities carried out by a company in its business or business to maintain viability in increasingly fierce business competition and to develop its business.

Pricing strategy is critical to do. That price is one of the elements that influence the activities of the company which functions to create a competitive advantage for the company. Pricing by companies must be adjusted to the environmental situation and the changes that occur, especially during times of increasingly intense competition and limited demand developments. The factor that is no less important regarding the marketing mix strategy is location. In a strategic location, an outlet will be more successful than other outlets that are less strategically located.

CV. Sumber Anugrah, a shop that sells building materials for a project or consumer needs which operates in the Bandung area tries to always increase customer satisfaction from time to time through strategies that can support its business. Amid increasingly fierce competition among business actors of this kind, it is possible to have a hard struggle to maintain its existence from the many material businesses in Indonesia in general and in the city of Bandung in particular. By increasing consumer satisfaction, it will significantly affect the intensity of consumer purchases in the future. The factor of pricing and location is a serious concern of the management.

\section{LITERATURE REVIEW}

According to Kotler (2003: 7), marketing is "a collective mechanism in 
which people and groups exist to acquire what they need and want by producing, selling and openly sharing useful goods with other parties."

According to Wiliam J. Stanton et al. Quoted by Djaslim Saladin (2003: 5) " Marketing is a complete business system designed to plan, price, promote and deliver satisfactory goods to target customers in order to achieve organizational goals". According to Paul et al. As quoted by Buchari Alma (2007: 4) "Marketing is defined as a purchasing and sale process and involves the distribution of products and services between producers and consumers". After knowing about marketing, there is also a theoretical basis regarding the notion of marketing management which will be described by several experts, including:

Philip Kotler and Gary Armstrong (2003: 16) explain that "Marketing management consists of evaluating, preparing, implementing and managing systems to develop, construct and monitor systems. In addition, maintaining advantageous exchanges with target customers to achieve organizational objectives".

According to Kotler and Amstrong (2010: 76), The marketing mix concept is the collection of controllable, tactical marketing tools that the organization combines to deliver the result it needs in the target.

According to Alma (2007: 205), explaining the technique for mixing marketing activities is a marketing mix, such that the maximum mixture is found to achieve satisfying results.

Ika Putri Iswayanti (2010) examines "Analysis of the Effect of Product Quality, Service Quality, Price, and Place on Purchasing Decisions at Soto Angkring Mas Boed restaurant in Semarang". The population in this study were guests who enjoyed Soto Angkring Mas Boed. Using the Non-Probability Sampling technique with the Accidental sampling strategy, namely the sampling process based on chance, samples were taken by as many as 100 respondents. Based on the results, the regression equation is obtained as follows: $Y=$ $0.260 X 1+0.253 \times 12+0.239 \times 3+0.206$ $\mathrm{X} 4+\mathrm{e}$. Based on statistical data analysis, the indicators in this study are valid, and the variables are reliable. The results of classical assumptions test, the regression model is multicollinearity-free, homoscedastic, and is distributed normally. The individual order of each variable that has the most influence is the variable product quality with a regression coefficient of 0.260 , then service quality with a regression coefficient of 0.253 , followed by price with a regression coefficient of 0.239 , while the variable with the lowest effect is the place with the coefficient regression of 0.206 .

Purnama (2011) examines "Analysis of the Influence of Products, Prices, and Locations on Purchasing Decisions at Toko Murah in Sukoharjo". Data obtained from the distribution of questionnaires of 100 consumers of cheap shops in Sukoharjo, The sampling method used was purposive sampling, then the data was analyzed quantitative and qualitative data analysis. Quantitative analysis includes validity and reliability tests, classical assumption tests, multiple regression analysis, hypothesis testing through t-test and $\mathrm{F}$ test, and analysis of the coefficient of determination (R2). Qualitative analysis provides information and explanations of the data obtained and the results from the statistical analysis. The results showed that the coefficient of determination seen in the Adjusted $\mathrm{R}$ Square was 0.636 , which means that the purchase decision could be explained by the three independent variables in this study, namely product, price, and location by $63.6 \%$, and the remaining $36.4 \%$-explained by other variables outside the research model. Partially based on the results of the t-test the variables in this study have a positive and significant effect where the product has the greatest influence compared to 
other variables in this study. In contrast, the price has the lowest effect on purchasing decisions. Based on the results of the $F$ test shows that simultaneously or together, the variables in this study, namely product, price, and location, have a positive and significant effect on purchasing decisions.

\section{METHOD, DATA, AND ANALYSIS}

In this study, the authors used primary data. While the forms of the technique used by the writer to obtain the required data are questionnaires and direct observation. The sample used in this research is using simple random sampling method with 100 respondents. According to Husein Umar (2004: 108), "simple random sampling is a method of taking the same sample to be selected as a sample". The definition of a sample, according to Sugiyono (2009: 116), is part of the number and characteristics possessed by this population. The data obtained were processed using SPSS software.

\section{RESULT AND DISCUSSION}

CV. Sumber Anugrah Bandung has many consumers or buyers. The consumers cover various types of buyers, regardless of gender and age. The author uses a saturated sample, where the population of consumers who come to CV. Sumber Anugrah was sampled. Thus, the authors get a sample of 100 respondents. Respondents are both male and female customers who buy at CV Sumber Anugrah. The sampling used randomly without paying attention to the latest education, occupation or other social strata in the population so that members of the population are considered homogeneous.

Based on the results of distributing questionnaires, the customer profile of CV. Sumber Anugrah based on gender, namely female respondents as many as 33 respondents or $33 \%$, while male respondents were 67 respondents or $67 \%$.

The validity and reliability test were used to test the data collection instrument. The results of the validity test showed that all questions were declared valid because the value of $r$ count was $\geq 0.1638$. The instrument can be said to be reliable because the Cronbach's alpha value is greater than 0.600 . Whereas in the reliability test, the results show the value of Cronbach's Alpha at Price $(X 1)$ of 0.603 , Location $(X 2)$ of 0.705 , and Purchase Decision (Y) of 0.745 . These results indicate that the data is reliable.

As proven data to be valid and reliable, the classical assumption test should be performed. The classical assumption test covers the test for Multicollinearity, Heteroscedasticity, Normality, and Autocorrelation.

Table 1. Multicollinearity Test Results of

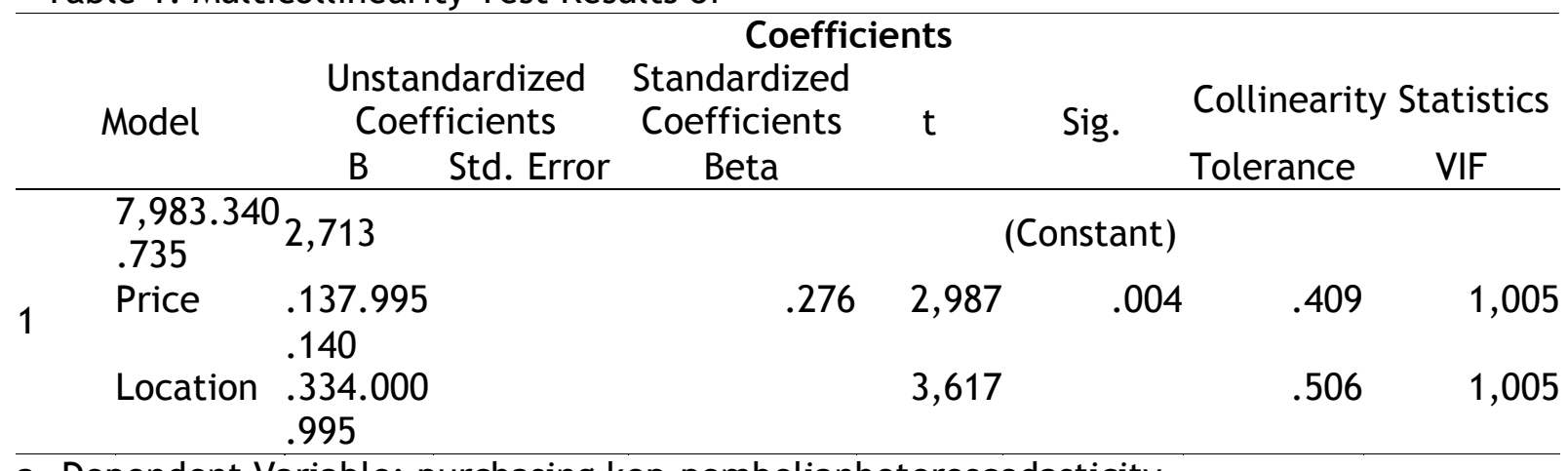

a. Dependent Variable: purchasing kep.pembelianheteroscedasticity

The multicollinearity test results showed the variance inflation factor (VIF) value of the two variables, namely $\mathrm{X} 1$ and $\mathrm{X} 2$, was 1.005. The VIF value of the two 
variables shows a number smaller than 10. So it can be concluded that the variables are multicollinearity-free.

There is no clear pattern and the points spread above and below the number 0 on the $\mathrm{Y}$-axis from the results of the test using a scatterplot. Thus, it can be concluded that heteroscedasticity does not occur in the regression model.

Figure 1. Heteroscedasticity Test Results

It can be seen from the results of the normality test using the PP Plot that the data scatter along the diagonal line and follows the diagonal line path. It can be seen from the results of the normality test using the PP Plot that the data scatter along the diagonal line and follows the diagonal line path. Hence, the regression model fulfils the assumption of normality. So it can be concluded that the data on variables $Y$, $\mathrm{X} 1, \mathrm{X} 2$ are normally distributed.

Figure 2. Normality Test Results

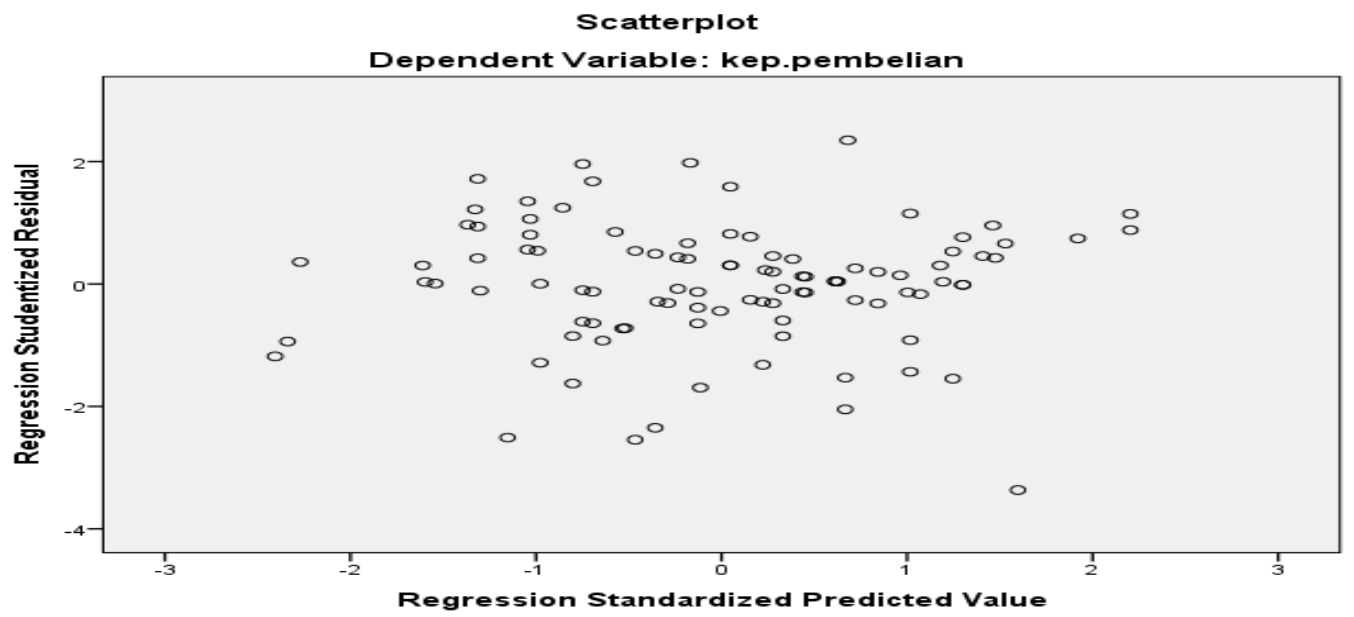

Normal P-P Plot of Regression Standardized Residual

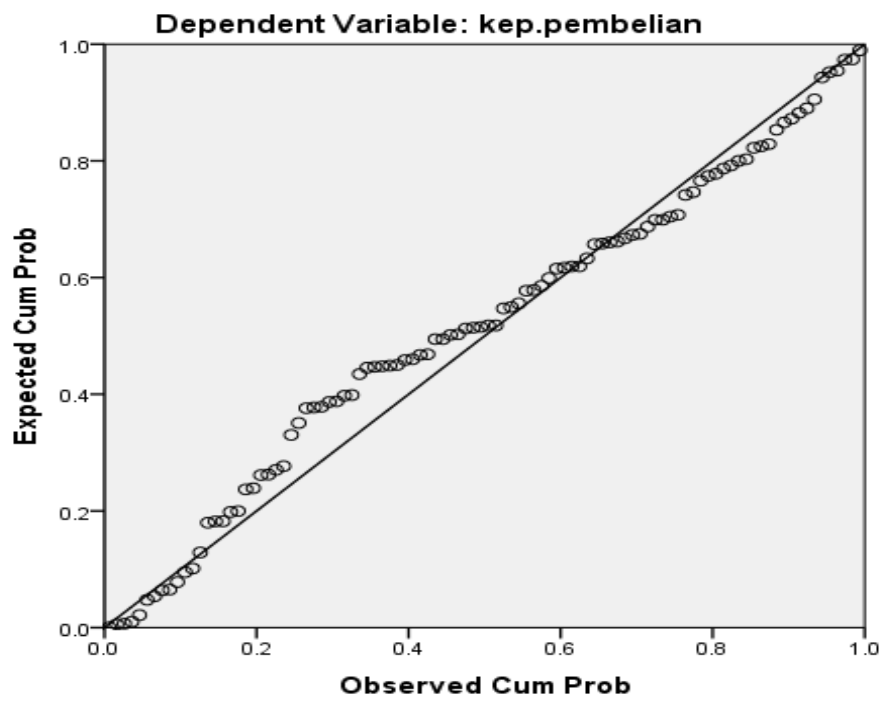


From the autocorrelation test results, it can be seen that the DW number generated from the regression model is 1,800 . Because the DW numbers are between -2 to +2 , it can be concluded that there is no autocorrelation problem found in the regression model.

Table 2. Autocorrelation Test Results

Correlation coefficient analysis and coefficient of determination

A correlation coefficient is a statistical analysis tool aimed at determining the relationship, the strength of influence and contribution between variable $X$ (independent) and variable $Y$ (dependent). In this study, the independent variables are Price and Location, and the dependent variable is the Purchasing Decision.

The coefficient of determination $\left(R^{2}\right)$ is important to calculate to which extent the model can explain the variation in the dependent variable. The value of coefficient of determination is between zero and one.

Table 3. Results of Correlation Coefficient and Coefficient of Determination Model Summary

\begin{tabular}{llllll}
\hline Model & $\mathrm{R}$ & R Square & $\begin{array}{l}\text { Adjusted } \\
\text { Square }\end{array}$ & $\begin{array}{l}\text { RStd. Error ofDurbin-Watson } \\
\text { the Estimate }\end{array}$ \\
\hline 1 & $.419^{\mathrm{a}}$ & .175 & .158 & 3,913 & 1,745 \\
\hline
\end{tabular}

a. Predictors: (Constant), location, price

b. Dependent Variable: purchasing decisions

From the results of the data processing above, it can be seen that the value of $R=0.419$. If we refer to the correlation coefficient interval

table written by Riduwan and Sunarto, then the independent variable has a moderate effect, and the correlation is moderate. However, it shows that $R$ is close to number 1 , and the relationship is unidirectional because it is positive.

From the results of the data processing above, it can also be seen that the coefficient of determination is 0.175 , which means that the

independent variable or price and location has a moderate effect on purchasing decisions.

Hypothesis Testing Results

Partial testing (t-test) was conducted to determine each independent variable on the dependent variable. The statistical test used in partial testing is the t-test. The table value used as critical in the $\mathrm{t}$-test is $\mathrm{a}=$ 0.05 . The Hypothesis in this partial test is:
Ho: there is no influence between variables $X 1$ and $X 2$, respectively, on variable $\mathrm{Y}$.

Ha: there is an effect of variables $\mathrm{X} 1$ and $\mathrm{X} 2$ respectively on variable $\mathrm{Y}$.

From the results of the t-test it can be seen that the Sig. for variables $\mathrm{X} 1$ and $X 2$, respectively, it is 0.0004 and 0.000 . Because of the Sig. variable $X 1$ is smaller than $\mathrm{a}=0.05$ or $5 \%$, so $\mathrm{Ho}$ is rejected, meaning that $X 1$ has a significant effect on $\mathrm{Y}$.

Table 4. Partial Regression Coefficient Test ( t-test)

Also, the Sig value of variable $\mathrm{X} 2$ is smaller than $a=0.05$ or $5 \%$, so $\mathrm{Ho}$ is rejected, meaning that $X 2$ has $a$ significant effect on $\mathrm{Y}$.

Simultaneous testing is carried out to collectively determine the effect of the independent variable on the dependent variable. The statistical test used in simultaneous testing is the $F$ test. The table value used as critical in the $F$ test is $\alpha=0.05$. 
Model Summary

\begin{tabular}{|c|c|c|c|c|}
\hline Model & $\mathrm{R}$ & R Square & $\begin{array}{l}\text { Adjusted R } \\
\text { Square }\end{array}$ & $\begin{array}{l}\text { Sta. Error of Durbin-Watson } \\
\text { the Estimate }\end{array}$ \\
\hline
\end{tabular}

\begin{tabular}{llllll}
\hline 1 & $.419^{\mathrm{a}}$ & .175 & .158 & 3,913 & 1,745 \\
\hline
\end{tabular}

a. Predictors: (Constant), location, price

b. Dependent Variable: purchasing decisions

Table 5. Results of the Regression Coefficient Test Together (Test F)

\begin{tabular}{|c|c|c|c|c|c|c|}
\hline & \multicolumn{6}{|c|}{ ANOVA $^{a}$} \\
\hline & Model & $\begin{array}{l}\text { Sum of } \\
\text { Squares }\end{array}$ & Df & $\begin{array}{l}\text { Mean } \\
\text { Square }\end{array}$ & $\mathrm{F}$ & Sig. \\
\hline \multirow{3}{*}{1} & Regression & 316,110 & 2 & 158,055 & 10,320 & $.000^{\mathrm{b}}$ \\
\hline & Residual & 1485,600 & 97 & 15,315 & & \\
\hline & Total & 1801,710 & 99 & & & \\
\hline
\end{tabular}

a. Dependent Variable: Purchase KepB.

.Predictors: (Constant), Location, Price

From the $\mathrm{F}$ test results, it can be seen that the Sig. for variables $\mathrm{X} 1$ and $\mathrm{X} 2$ together for 0.000 . Because the Sig is smaller than $a=0.05$ or $0.000<0.05$, then $\mathrm{Ho}$ is rejected, meaning that $\mathrm{X} 1$ and $X 2$ together have a significant effect on Y.

\section{CONCLUSION}

From the results of individual or partial hypothesis testing, it is concluded that the size of the relationship between the variable $\mathrm{X} 1$ (price) is 0.004 to $\mathrm{Y}$ (Purchase Decision). This means that it shows the influence of variable $\mathrm{X} 1$ (price) on variable $Y$ (purchase decision).

Also, conclusions are obtained from the results of hypothesis testing individually or partially. The magnitude of the influence of the variable $\mathrm{X} 2$ (Location) is 0,000 on $Y$ (Purchase Decision). This means that it shows the influence of the variable $X 2$ (Location) on the $Y$ variable (Purchase Decision).

The results show that Price and Location effect is 0.000 . The value shows that the two variables $X 1$ (Price) and $X 2$ (Location) affect Variable $Y$ (Purchase Decision).

\section{IMPLICATION / LIMITATION AND SUGGESTION}

The results showed that Price and Location greatly influence Purchasing Decisions. Therefore, companies often promote their products by paying attention to price and location, because these two instruments are essential to influence customer satisfaction. Then the company must pay more attention to its managed words so that the company can influence consumers by the price and location variables studied because both have been proven from 
simultaneous tests that together have a very significant effect.

For further researchers, it is advisable to add independent variables that can influence purchasing decisions such as the Marketing Mix and Promotion Mix as a whole and examine them on objects using more respondents so that the data obtained is expected to represent the real situation.

\section{REFERENCE}

Alma, Buchari, 2007, Manajemen Pemasaran dan Pemasaran Jasa, Alfabeta, Bandung.

Cannon, dkk, 2008, Pemasaran Dasar, Edisi 16 Pendekatan Manajerial Global, Salemba 4, Jakarta.

Ghozali, Imam, 2005, Aplikasi Analisis, Multivariate dengan Program SPSS, Badan Penerbit Universitas Diponegoro.

Kotler, Philip dan Garry Amstrong, 2008, Prinsip-prinsip Pemasaran, Jilid 1, Erlangga, Jakarta.

Kotler, Philip dan Gary Amstrong, 2003, Dasar-dasar Pemasaran, Jilid 2, Edisi Kedelapan, Erlangga, Jakarta.

Kotler, Philip dan Keller, 2009, Manajemen Pemasaran, Edisi 12, Indeks, Jakarta.

Kotler, Philip, 2003, Manajemen Pemasaran, edisi kesebelas, Indeks kelompok Gramedia, Jakarta.

Kotler, Philip, 2005, Manajemen Pemasaran, Jilid 1 dan 2, Indeks Kelompok Gramedia, Jakarta.

Kotler, Philip, 2006, Manajemen Pemasaran, Edisi Kedua, PT. Indeks, Jakarta.
Nugroho, 2003, Perilaku Konsumen, Konsep dan Implikasi Untuk Strategi dan Penelitian Pemasaran, Prenada, Jakarta.

Riduwan dan Sunarto, 2011, Pengantar Statistika, : Untuk Penelitian Pendidikan, Sosisal, Ekonomi, Komunikasi, dan Bisnis, Alfabeta, Bandung.

Ruslan, Rosadi, 2003, Metode Penelitian PR dan Komunikasi, PT. Raja Grafindo, Jakarta.

Saladin, Djaslim, 2003, Manajemen Pemasaran, Linda Karya, Bandung.

Santosa dan Ashari,2005, Riset Pemasaran, PT. Gramedia Pustaka Utama, Jakarta.

Sugiyono, 2002, Metode Penelitian Bisnis, Buku 1, Alfabeta, Bandung.

Sugiyono, 2005, Metode Penelitian Kualitatif, Alfabeta, Bandung.

Sugiyono, 2009, Metode Penelitian Kuantitatif, Kualitatif dan R\&D, Alfabeta, Bandung.

Swastha, Basu dan Irawan, 2003, Manajemen Pemasaran Modern, Edisi Kedua, Cetakan Kesebelas, Liberty Offset, Yogyakarta.

Swastha, Basu dan Sukotjo, 2007, Pengantar Bisnis Modern, Liberty, Yogyakarta.

Tandjung. J.W., 2004, Marketing Manajemen : Pendekatan Nilai-nilai Pelanggan, Edisi Kedua, Cetakan Kedua, Bayu Media Publishing, Malang.

Umar, Husein, 2004, Metode Penelitian Untuk Skripsi dan Tesis Bisnis, Cetakan ke 6, PT. Raja Grafindo Persada. 